\title{
TRADE FINANCE FOR SUSTAINABLE DEVELOPMENT IN ASIA AND THE PACIFIC
}

\author{
Sailendra Narain*
}

\begin{abstract}
Over the years, the Asia-Pacific region has maintained its global lead position as the largest user of trade finance. Actively involved in international trade, Asian and Pacific small and medium-sized enterprises have been important contributors for sustaining the region's lead position. Juxtaposed to the interregional high position enjoyed by the Asia-Pacific region as the largest user of trade finance in the world market, trade within the region is facing a persistent demand-supply mismatch and widening of trade finance gaps. Small and medium-sized enterprises, despite being the largest contributors to Asian international trade, are more adversely affected than large companies, giving rise to operational constraints and challenges. This has prompted some policymakers, national governments and international organizations to address the issues, invite suggestions to halt the persistent trend of the widening of trade finance gaps and take suitable measures to ease the flow of trade finance.
\end{abstract}

Recognizing the importance and significant role of trade finance as an engine of growth, this paper reviews the status of and constraints to easy access to trade finance in Asia and the Pacific; assesses trade finance gaps estimated by institutional surveys; and identifies emerging issues and challenges, especially those faced by the small and medium-sized enterprise sector. Analysing the resultant policy implications, the paper finally brings to the forefront a set of remedial measures, presents recommendations together with a road map for policymakers to consider for implementation. The recommendations are innovative and suggestive of national action and regional cooperation.

JEL classification: L53, G01, G28.

Keywords: SME trade finance, SME financing, SME sustainable development.

Sailendra Narain, PhD, Chairman, Centre for SME Growth and Development Finance, India. The author would like to express his gratitude and sincere thanks to Mia Mikic, Marc Proksch, Yann L. Duval, Masato Abe and Mona Narain for reviewing and editing the paper and providing comments with valuable suggestions. 


\section{INTRODUCTION}

The flow of bank-intermediated trade finance is falling short of meeting the growing demands in the Asia-Pacific region. While the Asia-Pacific region has been the largest user of trade finance globally, the persistent trade finance gaps in the recent past have been inhibiting business development, job creation and growth, especially for small and medium-sized enterprises (SMEs). Even with its large presence and sizable contribution to the Asia-Pacific economy, the SME sector has been more adversely affected than the large companies by the gap in bank-intermediated finance (ADB, 2014). The problems are continuing and the gap is widening. This has prompted some policymakers to identify the roadblocks and find ways and means to meet the challenges. The present paper reviews the status of trade finance in the Asia-Pacific region, highlights the specific issues (obstacles and the needs) faced by SMEs with regard to accessing trade finance and presents a set of recommendations for national action and regional cooperation.

Recognizing the importance and significant role of trade finance as an engine of growth, this paper proceeds with a review of trade finance in the Asia-Pacific region - its status and constrains, followed by an assessment of trade finance gaps identified by institutional surveys, the resultant policy implications, emerging issues and the challenges, especially those faced by the SME sector, and finally, brings to the forefront a set of recommendations along with a road map for policymakers to consider. In addition, a few major issues are presented for thinking ahead. The recommendations are innovative, calling for much-needed conceptual, systemic and operational changes to be implemented comprehensively at the national level with a built-in regional cooperation mechanism.

\section{TRADE FINANCE IN ASIA AND THE PACIFIC: MODALITIES, STATUS AND CONSTRAINTS}

\section{Asia-Pacific international trade}

Before an analysis is made of the trade finance situation in the Asia-Pacific region, it is perhaps useful to review the current trade situation in the region.

Contrary to the global lead position retained by the Asia-Pacific region in terms of using trade finance, growth in merchandize goods exports in the region slowed gradually from 29.9 per cent in 2010 to 19.5 per cent in 2011 and then to 2.2 per cent in 2012 before reaching a new low of 2.1 per cent in 2013. A similar slowdown from 4.3 per cent in 2012 to 2.3 per cent in 2013 was recorded in the imports of merchandise goods. Despite the gradual slowdown, the region accounted for 36 per 
cent of global merchandise exports and 36.1 per cent of global merchandise imports, "making it the biggest trading region in the world, in terms of both imports and exports, overtaking Europe in 2012" (ESCAP, 2014, p. 28). However, the current slowdown of economic growth and trade in China is likely to put a damper on an increase in the intraregional trade volume.

The ESCAP Statistical Yearbook 2014 observes that "in order to enhance the competitiveness of a country in the world of globalized production, focus needs to be placed on raising domestic value-added rather than just increasing gross exports".

\section{Overview of trade finance}

During the period 2013-2014, despite witnessing phases of both "ups and downs", the Asia-Pacific region remained the largest user of trade finance and trade credit insurance globally (CGFS, 2014, p. 9 and graph 2, p.11).

Over the years, the Asia-Pacific region has been able to enhance and widen the use of trade finance for business. The progressive increase in trade finance by volume and demand is indicative of the importance the region attaches to trade finance as one of the contributory factors and prime movers to growth.

Trade finance mechanisms provide a combination and degree of support in the following four areas (ITC, 2009):

(1) Payment facilitation, enabling secure and timely payment across borders, for example, through proven communication methods, such as SWIFT $^{1}$ (a secure bank-to-bank messaging system used to transmit bank instruments, such as letters of credit, as well as payments between financial institutions).

(2) Financing to one or more parties in a trade transaction, whether it is the importer, exporter, or one of the banks.

(3) Risk mitigation, either directly through the features available in a trade financing mechanism or indirectly through insurance or guarantee products designed to meet the needs of importers and exporters.

(4) Providing information on the movement of goods and/or the status of the related financial flow.

The matrix of trade finance instruments commonly used is given below (table 1).

Society for Worldwide Interbank Financial Telecommunication. 


\section{Table 1. Matrix of trade finance instruments commonly used for raising capital, facilitating payments and mitigating risks}

Raising working capital for exports: debt financing; asset-based financing; export factoring; and leasing

Facilitating payments: cash-in-advance; letter of credit (L/C); documentary collection; and open accounts

Mitigating risks: export credit guarantee; export credit insurance; forfeiting; and hedging.

Source: Compiled by the author.

Note: Warehouse receipts are also in use as specialized financial instrument for commodity trade.

\section{The role of the banking sector and other actors in trade finance}

Trade finance assistance is mainly provided by the commercial banks and development financial institutions (DFIs). Bank-intermediated trade finance acts as the lifeline for trade and commerce, especially in the field of international trade. Banks are the main providers of trade finance in various forms of working capital at a much reduced payment risk as compared to the finance from non-institutional sources. Inter-firm trade credit is slowly emerging as a non-banking channel of trade finance. A firm's ability to directly extend credit, however, primarily depends on interfirm business relationships with trust and is generally backed by purchasing trade credit insurance to mitigate payment risks.

A commercial bank acts as a trusted third party to guarantee delivery of goods and services from the exporter and payment by the importer. Many Asia-Pacific countries have set up national SME Banks, such as BRAC Bank-Bangladesh, Small Industries Development Bank of India (SIDBI), Philippines SME Bank Inc., SME Bank of Thailand, which, among other things, extend trade finance and offer risk mitigating products (see Abe and others, 2012).

An overview of the schemes and services offered by SIDBI provides examples of best practices in SME trade financing. SIDBI, in addition to providing financing in general and resource support to the banking sector and financial institutions, offers a full range of traditional and innovative trade finance products/services, including business development services to the SME sector at large. It has successfully implemented an innovative collateral-free and third party guarantee-free credit guarantee scheme for the micro, small and medium-sized enterprises in collaboration with the Government of India, which had been in operation for about 15 years (box 1). 


\section{Box 1. Trade finance schemes, products and services of the Small Industries Development Bank of India for small and medium-sized enterprises}

The Small Industries Development Bank of India, established in April 1990 under an act of the Indian Parliament, is the "principal financial institution for the promotion, financing and development of the micro, small and medium enterprise sector and for coordination of the functions of the institutions engaged in similar activities". Facilitating access to finance by SMEs has been one of the prime areas of concern for SIDBI. The bank has therefore designed a number of relevant financial products and services to meet the demand for finance.

The Small Industries Development Bank of India, in addition to various financial schemes and business development services (BDS), has effectively implemented trade finance schemes for SMEs. Some of the widely used trade finance schemes operated by SIDBI for SMEs are trade financing and factoring services, lines of credit in foreign currency to commercial banks (LOCFC) for on-lending to exporting SMEs, export houses/trading houses sourcing their export requirements from micro, small and medium-sized enterprise receivable finance scheme and discounting scheme.

The collateral-free and third party guarantee-free Credit Guarantee Fund Scheme for Micro and Small Enterprises is an innovative and successful credit risk mitigation initiative of SIDBI. This solves the problem of the inability of SMEs to meet the most vexing demand for collateral and guarantees to access bank finance. The scheme helps small entrepreneurs to obtain collateral free loans (including trade finance) of up to 10 million Indian rupee (Rs) $(\$ 147,000)$. As of the end of January 2013, more than one million guarantees (by number of entrepreneurs) for an aggregate loan amount that exceeded Rs480 billion had been provided under the Credit Guarantee Fund Trust for Micro and Small Enterprises (CGTMSE).

Under the Union Budget 2013/14, the establishment of the Credit Guarantee Fund for Factoring was announced with a fund of Rs 5 billion. This fund will further pave the way for orderly growth of factoring services and provide an alternative to bank-intermediated trade credit.

The main channel for institutional trade finance to micro, small and medium enterprises is the commercial banking sector. SIDBI serves the sector by providing resource support to a country-wide banking sector network of more than 80,000 branches. It is ranked among the top 30 development banks of the world as rated by The Banker, London.

Source: www.sidbi.in. 
In the Asia-Pacific region, there are four common methods of payments available to firms engaged in international trade: (a) cash-in-advance, (b) letters of credit (L/Cs), (c) documentary collection, and (d) open account (table 2).

\section{Table 2. Methods of payment in international transactions}

\begin{tabular}{|c|c|c|c|c|}
\hline $\begin{array}{l}\text { Method of } \\
\text { payment }\end{array}$ & Definition & Applicability & $\begin{array}{c}\text { Risk } \\
\text { distribution }\end{array}$ & $\begin{array}{c}\text { Pros/cons for } \\
\text { exporter }\end{array}$ \\
\hline $\begin{array}{l}\text { Cash in } \\
\text { advance }\end{array}$ & $\begin{array}{l}\text { Full payment } \\
\text { prior to } \\
\text { shipment }\end{array}$ & $\begin{array}{l}\text { Recommended for } \\
\text { high risk export } \\
\text { markets }\end{array}$ & $\begin{array}{l}\text { Exporter is } \\
\text { exposed to } \\
\text { virtually no } \\
\text { risk; burden } \\
\text { is greatest on } \\
\text { the importer }\end{array}$ & $\begin{array}{l}\text { Pros: Payment before } \\
\text { shipment, eliminates } \\
\text { risks of non-payment } \\
\text { Cons: May lose } \\
\text { customers to competition } \\
\text { over payment terms }\end{array}$ \\
\hline $\begin{array}{l}\text { Letter of } \\
\text { credit (L/C) }\end{array}$ & $\begin{array}{l}\text { A commitment } \\
\text { by a bank on } \\
\text { behalf of the } \\
\text { buyer that } \\
\text { payment will } \\
\text { be made to the } \\
\text { exporter when } \\
\text { the terms and } \\
\text { conditions of } \\
\text { the L/C are met }\end{array}$ & $\begin{array}{l}\text { Recommended in } \\
\text { new and } \\
\text { established trade } \\
\text { relationships; } \\
\text { exporter should } \\
\text { be confident of the } \\
\text { credit worthiness } \\
\text { of buyer's bank }\end{array}$ & $\begin{array}{l}\text { Evenly } \\
\text { spread } \\
\text { between } \\
\text { seller and } \\
\text { buyer if } \\
\text { conditions } \\
\text { are adhered } \\
\text { to }\end{array}$ & $\begin{array}{l}\text { Pros: Transaction is } \\
\text { secured by a third party. } \\
\text { Goods against payment. } \\
\text { Cons: Complex and } \\
\text { labour-intensive process. } \\
\text { Relatively expensive. }\end{array}$ \\
\hline $\begin{array}{l}\text { Documentary } \\
\text { collection }\end{array}$ & $\begin{array}{l}\text { Exporter } \\
\text { entrusts the } \\
\text { collection of } \\
\text { payment to } \\
\text { a bank with } \\
\text { payment } \\
\text { instructions }\end{array}$ & $\begin{array}{l}\text { Recommended in } \\
\text { established trade } \\
\text { relationships and } \\
\text { in stable markets }\end{array}$ & $\begin{array}{l}\text { Riskier for } \\
\text { the exporter } \\
\text { but cheaper } \\
\text { than L/Cs }\end{array}$ & $\begin{array}{l}\text { Pros: Payment is made } \\
\text { with the assistance of } \\
\text { a bank. The process is } \\
\text { simple, fast and less } \\
\text { costly than L/Cs } \\
\text { Cons: Bank role is limited, } \\
\text { payment is not guaranteed }\end{array}$ \\
\hline $\begin{array}{l}\text { Open } \\
\text { account }\end{array}$ & $\begin{array}{l}\text { Payment by } \\
\text { importer after } \\
\text { receiving the } \\
\text { goods, usually } \\
\text { within a } \\
\text { timeframe of } \\
30 \text { to } 90 \text { days }\end{array}$ & $\begin{array}{l}\text { Recommended in } \\
\text { low-risk trading } \\
\text { relationships or in } \\
\text { a competitive } \\
\text { market to win new } \\
\text { customers (should } \\
\text { be combined with } \\
\text { one or more trade } \\
\text { finance techniques) }\end{array}$ & $\begin{array}{l}\text { Significant } \\
\text { risk to } \\
\text { exporter } \\
\text { because } \\
\text { buyer could } \\
\text { default } \\
\text { on payment } \\
\text { after goods } \\
\text { are shipped }\end{array}$ & $\begin{array}{l}\text { Pros: Boosts } \\
\text { competitiveness } \\
\text { in the global market; } \\
\text { helps establish and } \\
\text { maintain a successful } \\
\text { trade relationship } \\
\text { Cons: Significant risk of } \\
\text { non-payment; additional } \\
\text { costs associated with } \\
\text { risk mitigation measures }\end{array}$ \\
\hline
\end{tabular}

Source: ITC (2009, table 3.1, pp. 35-36). 
Firms in the Asia-Pacific region have been relying mainly on banks' short term maturity products, namely L/Cs and documentary collection for their export transactions. This mode of international payment obligations has so far been considered as a liquid, low-cost payment risk, time-tested and well-functioning mode for overseas business transactions. However, in the changing global market and with growing demand, heavy reliance only on these traditional modes of payment is no longer sufficient to meet market requirements and unmet credit needs of SMEs. Therefore, the wider use of interfirm transactions, such as an "open account system" backed by suitable risk mitigation mechanism and other support mechanisms, is necessary.

\section{Market size of trade finance: global and regional}

There is no comprehensive single source to determine and measure the global and regional size of trade finance and the composition of the trade finance market. Different sources use their own modalities and conduct surveys to measure the bank-intermediated trade finance size, structure and developments, including:

- The Society for Worldwide Interbank Financial Telecommunication (SWIFT) provides a window to trends related to documentary credits, such as L/Cs. It helps to track high frequency global and regional transactions.

- The International Chamber of Commerce (ICC) collects data from a number of banks considered to be the global leaders in providing trade finance. Currently, the ICC Annual Global Trade Finance Survey is the main broad industry document for exploring drivers and trends (ICC, 2014a).

- $\quad$ The International Monetary Fund (IMF), in conjunction with the Bankers' Association for Finance and Trade (BAFT) and the International Financial Services Association (IFSA), undertook a series of surveys (2009, 2010, and 2011) on volumes, pricing and drivers in the trade finance market. Another survey was undertaken by ICC in 2011 in collaboration with IMF.

- $\quad$ The Institute of International Finance (IIF) undertakes the quarterly Emerging Markets Bank Lending Conditions Survey and currently collects responses on trade finance markets from 130 banks. IIF conducts a quarterly survey among banks based in five emerging markets regions: Emerging Asia, Latin America, Emerging Europe, Middle East and North Africa and Sub-Saharan Africa. The available statistics, however, show significant variation across countries and regions (see www.iif.com). 


\section{Global market}

The Committee on the Global Finance System (CGFS) (CGFS, 2014, table 2, p. 10), based on national statistics, SWIFT and the ICC Trade Register Survey, estimated that trade finance directly supported about one third of global trade, with L/Cs covering about one sixth of total trade. The Survey mentions that the bank-intermediated products are primarily used to finance trade involving emerging markets economies, particularly in Asia. Global banks appear to provide about one quarter to a third of the global trade finance, and almost half of their exposure is to firms in emerging Asia. The global market size of bank-intermediated trade finance was estimated by CGFS to amount to $\$ 6.5$ trillion-8 trillion in 2011 , of which around $\$ 2.8$ trillion was provided through L/Cs. IMF, jointly with BAFT and IFSA (2009; 2010; 2011), estimated that about 40 per cent of global trade was supported by bank-intermediated trade finance, while industry studies (ICC, 2009) estimated it to be about 20 per cent.

\section{Regional: Asia-Pacific market}

Data of individual economies show a wide variation in the measurements of trade finance stocks and annual flows, and the percentage of merchandise trade covered by trade finance, which ranges from 2 per cent for Mexico to more than 40 per cent for China (47 per cent), India (41 per cent), Hong Kong, China (29-38 per cent), and the Republic of Korea (56 per cent) as compared to global estimates at 36-40 per cent. The percentages of measured intensity of trade finance over trade ranged from 29-38 per cent to 56 per cent relating to major Asia-Pacific economies (table 3).

Table 3. Bank-intermediated trade finance markets in 2011

\begin{tabular}{lccc}
\hline Country/territory & $\begin{array}{c}\text { Trade finance } \\
\text { \$ billion: stocks }\end{array}$ & $\begin{array}{c}\text { Trade finance \$ billion: } \\
\text { annual flows }\end{array}$ & $\begin{array}{c}\text { Percentage of } \\
\text { merchandise trade }^{\mathbf{c}}\end{array}$ \\
\hline China & 218 & 871 & 47 \\
Hong Kong, China & 44 & $131-175$ & $29-38$ \\
India & 82 & 164 & 41 \\
Republic of Korea & 76 & 304 & 56 \\
Global estimates & $1625-2100$ & $6500-8000$ & $36-40$ \\
\hline
\end{tabular}

Source: ICC; IMF, national data; and CGFS (2014, table 2, p.10).

Notes: $\quad$ a Average quarterly stock for 2011.

b Annual flows for national data are derived by assuming a 90-day maturity of stocks, except in India (and Mexico) where maturities are known to be six months for India (and 12 months for Mexico).

${ }^{c}$ Trade is measured as the average of exports and imports of goods. 
Figure 1 shows that the Asia-Pacific region relied most heavily on trade finance among the regions in the world.

\section{Figure 1. Geographical distribution of trade finance (as a share of total, in per cent)}

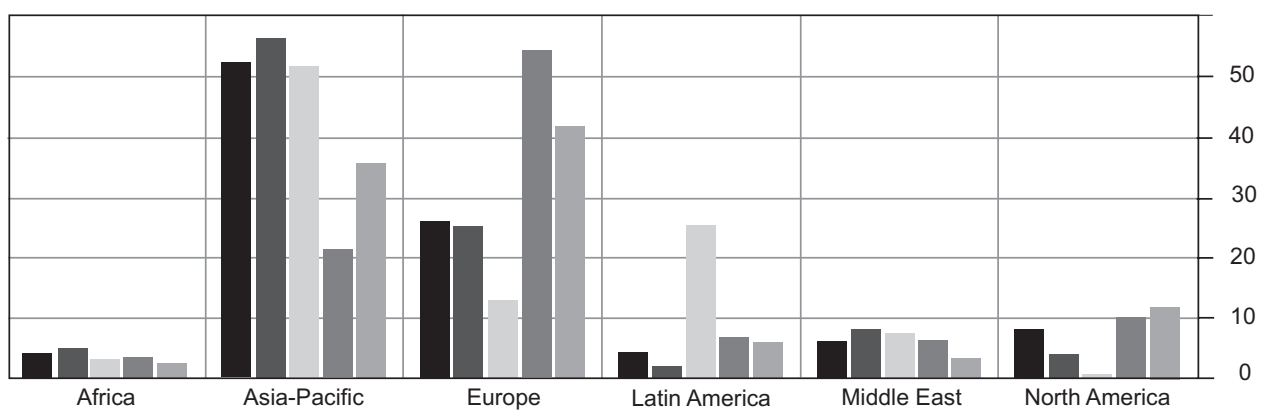

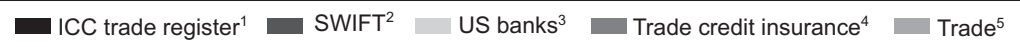

Source: Committee on the Global Financial System (2014, p. 11)

Notes: $\quad{ }^{1}$ Average from 2008 to 2011.

2 Based on average value of sent and received SWIFT MT700 messages in 2011.

${ }^{3}$ The US data capture only lending vis-à-vis non-residents resulting in a low share of US banks' exposure to North America. Average from 2008 to September 2012.

${ }^{4}$ Short term credit insurance from the Berne Union. Average for Q4 2011 to Q1 2013.

${ }^{5}$ Merchandise trade (average of imports and exports) from Q1 2008 to Q4 2012.

There are various logistic and economic factors contributing to the higher use of trade finance in the Asia-Pacific region. Among them are long distance trade transactions between partners, level of local market efficiency, new trade relationships, expanded trade with countries with weaker legal and contractual systems, political risks, historical preferences and costs of operating through L/Cs. The above-mentioned factors may be more pronounced in countries with foreign exchange regulations or strict banking regulations.

\section{Users of letters of credit}

The ICC Trade Register estimates that about 90 per cent of the L/C transactions go through SWIFT. As noted before, of the total flow of bankintermediated global trade finance, which was estimated at $\$ 6.5$ trillion-8 trillion, about $\$ 2.8$ trillion was through L/Cs in 2011. The Asia-Pacific region accounted for more than half of all L/C-related transactions, while Europe accounted for one quarter 
and North America, Latin America, Africa, and the Middle East each around 5-10 per cent. The Asia-Pacific region registered the highest volume of L/Cs used, covering 75 per cent of exports and 68 per cent of imports.

\section{Factoring in the Asia-Pacific region}

The overall global factoring volume in 2013 was $\$ 3.1$ trillion, recording nearly 10 per cent growth. Europe followed by Asia and the Pacific jointly accounting for about 87 per cent of the global factoring volumes (figure 2). Over the past five years, the factoring industry has grown annually at a rate of 15 per cent, nearly doubling in size globally.

Factoring in the Asia-Pacific region is gradually gaining popularity as a product designed to provide finance to SMEs. Funding is offered by the factoring companies based upon the accounts receivables created by the client. China and Hong Kong, China are the Asia-Pacific economies with most factoring facilities.

Figure 2. Global factoring by region

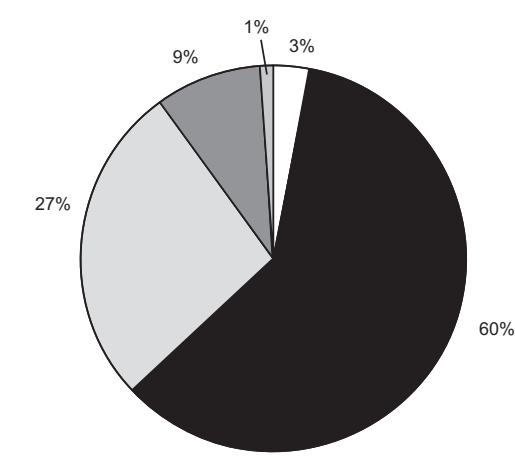

(In billions of Euro)

\begin{tabular}{lrrc}
\hline & $\mathbf{2 0 1 2}$ & $\mathbf{2 0 1 3}$ & \% change \\
\hline Europe & 1298 & 1354 & 4.3 \\
Asia & 572 & 599 & 4.7 \\
Americas & 188 & 192 & 2.1 \\
Africa & 23 & 23 & 0.0 \\
Others & 50 & 62 & 24.0 \\
Total & 2132 & 2230 & 4.6 \\
\hline
\end{tabular}

Europe Asia $\square$ Americas $\square$ Africa $\square$ Others

Source: Factors Chain International (2014, table 1, p. 20).

Note: $\quad 1$ euro $=\$ 1.12$.

\section{Forfaiting in the Asia-Pacific region}

Comparative and comprehensive data are not readily available on the volume of trade finance transactions through forfaiting in the Asia-Pacific region. 
Under the forfaiting system of trade finance, international trade receivables, such as promissory notes, bills of exchange, receivables and deferred payment under letters of credit guaranteed or issued by banks, with credit periods ranging from 90 days up to 5 years, are discounted without recourse to the exporter. Over the years, this facility has emerged as an effective sales tool in the Asia-Pacific region. It improves cash flows and eliminates risks. A number of major companies have started to offer forfaiting services in the region. This trend is gaining ground.

\section{Global value chains and Asia-Pacific small and medium-sized enterprises}

Most Asia-Pacific economies are well integrated into the global trading system. The Asia-Pacific region is witnessing a gradual emergence and expansion of global and regional supply or value chains systems benefitting SMEs. However, the process in the region is slow.

The term "global value chains" (GVCs) refers to the full range of cross-border, value-added business activities that are required to bring a product or service from the conception, design, sourcing raw material, and intermediate inputs stages, to production, marketing, distribution and supplying the final consumer (ESCAP, 2007).

Small and medium-sized enterprises participate as suppliers, distributors and business service providers by entering into GVCs. In Asia and the Pacific, both producer-driven chains and networks, such as Tata Motors and Toyota sourcing automotive components from a large number of small suppliers, and buyer-driven chains or networks, such as Levi's in the apparel market, systems are prevalent.

In the supply chains system, the lead firm decides some of the key details, including, among them, information pertaining to outsourcing, capacity-building of the suppliers for quality control and product standardization. SMEs as global suppliers offer the products and services to the lead firm. The GVC framework offers room for multiple SMEs to provide services based on their experience and expertise as suppliers, distributors and business service providers (Abe and others, 2012).

The development of GVCs in Asia and the Pacific provides business opportunities for export-oriented and supporting industry SMEs (ESCAP, 2009b). GVCs are expected to provide an efficient network by establishing links with large enterprises or even with other efficient SMEs. They help to boost the value-added activities of affiliated SMEs in international trade by providing an established market. However, Asia-Pacific SMEs currently play a limited role due to low value-addition and lack of proper networking. SMEs are generally at a disadvantage because of their limited operational capacity and lack of knowledge necessary to penetrate regional and global markets (ESCAP, 2007). SMEs in the Asia-Pacific developing countries typically lack the environment to improve their capacity, including a proper policy and 
regulatory framework, supporting infrastructure, access to finance, a strong entrepreneurship culture, technology incubation and business development services (ESCAP, 2009a).

Global value chains are an effective way to expose SMEs to foreign markets. There are a number of benefits for SMEs to join these chains, but the main advantage is that GVCs increase SMEs competitiveness and widen the scope of international trade. Some of the initiatives taken to promote supply chains system-related trade finance are given below:

For instance, the Global Trade Supplier Finance (GTSF), a $\$ 500$ million multicurrency investment and advisory programme, was established by the International Finance Corporation (IFC) in 2010 (box 2). It has started to show positive

\section{Box 2. The Global Trade Supplier Finance programme}

The following paragraphs have been extracted from the IFC-GTSF website.

"GTSF extends and complements the capacity of banks to deliver trade financing by providing risk mitigation in new or challenging markets where trade lines may be constrained. IFC issues credit guarantees where others won't and supports trade that would not be possible without an IFC guarantee. Through the Global Trade Finance Program (GTFP) bank network, local financial institutions ("issuing banks") can establish working partnerships with a vast number of major international and regional banks ("confirming banks") in the programme, thus broadening access to finance and reducing cash collateral requirements. GTFP offers confirming banks partial or full guarantees covering payment risk on banks in the emerging markets for individual trade-related transactions evidenced by a variety of underlying instruments, such as L/Cs, traderelated promissory notes, accepted drafts, bills of exchange, guarantees, bid and performance bonds and advance payment guarantees. Guarantees are available for all private sector trade transactions that meet eligibility criteria of IFC. Trade Advisory Services extended by IFC include more than a dozen technical assistance modules to provide basic and intermediate trade finance skills for issuing banks.

"The GTSF programme aims to: increase access to finance for suppliers in emerging markets; maximize inclusion of SMEs and their ability to access finance at competitive terms; support reduction in financing costs; and develop market appetite for supplier finance."

Source: www.ifc.org. 
results in benefitting SME suppliers from emerging economies. SMEs are increasingly, though slowly, joining the IFC Global Supply Chain support programme for making cross-border transactions.

Developing more programmes similar to GTSF seems a workable solution and an alternate source to ease the pressure on banks' intermediation. Figure 3 shows the two GVC-related trade finance programmes of IFC, GTSF discussed above and the Global Warehouse Finance Program.

Figure 3. The global value chain-related trade finance programmes of the International Finance Corporation
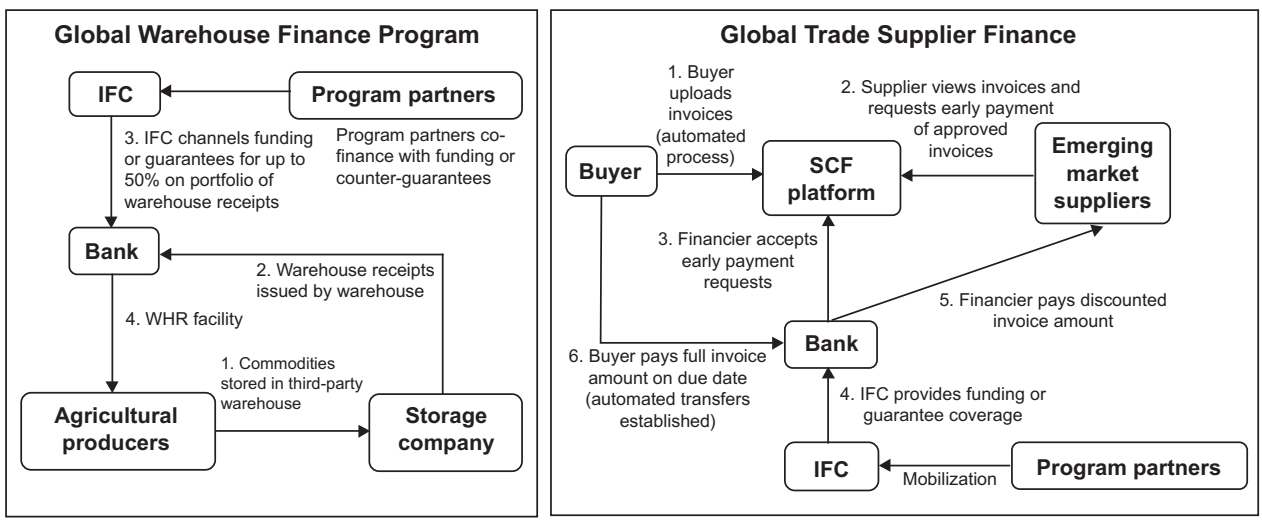

Source: International Finance Corporation (2012).

Gartner, Inc., a leading information technology research and advisory global company, in its 2014 annual list of the leading supply chains in the Asia-Pacific region, ranked "ten of the best supply chains in Asia and the Pacific" key strategies, initiatives and best practices. Samsung, Lenovo and Toyota ranked as the top three of the list. These multinational companies are benefitting a large number of SMEs through their supply chains system.

The above scenario of supply chain position in Asia and the Pacific seems to offer enough potential and scope to enhance SMEs integration into GVCs. The Asia-Pacific Economic Cooperation (APEC), in its survey Integrating SMEs into Global Value Chains: Policy Principles and Best Practices, which was published in May 2014 (see Zhang, 2014), observed that SMEs in developed and newly industrialized economies, particularly in the agriculture and electronics sectors, offer higher potential to participate in GVCs. 
Access to trade finance, both globally as well as in the Asia-Pacific region, has been the key obstacle for exporting SMEs. More than 60 per cent of the exporting SMEs in the Asia-Pacific region rely on internal financing. Sources other than bank-intermediated finance, particularly supply chain financing, is perceived as advantageous to facilitate the direct export participation of SMEs (see Duval and Utoktham, 2014).

\section{Inter-firm trade credit}

The system of inter-firm trade credit between importers (not necessarily manufacturers) and exporters is an alternative to trade finance extended by the banking sector; it is different from credit afforded under supply chains system, which are operated by large manufacturing companies. The system of inter-firm trade credit is based on business relationships and trusts. It includes open account transactions in which goods are shipped in advance of payment, or through cash-in-advance transactions in which payment is made before shipment. This type of transaction involves lower fees and has greater flexibility, but higher payment risks. Hence, reliance on this form of transaction is mostly confined to firms with well-established commercial relationships. In Viet Nam, the system of inter-firm credit has been in existence for a long time. A firm trusts its customers enough to offer credit when the customer finds it hard to locate an alternative supplier. A longer duration trade relationship is associated with large credit. Customers identified through the business network receive more credit (see MacMillan and Woodruff, 1999).

\section{Other new non-banking products}

Global banks see supply chains finance as an important new area of activity, and a focal point of current competition. Citing new regulatory demands and high marginal costs of equity capital, the trade finance industry is experimenting, though on a limited scale, with new structures and products to distribute trade finance to non-bank companies.

For instance, the Royal Bank of Scotland introduced a suite of non-traditional global trade finance products, which provide visibility in supply chains events, such as the purchase-to-payment and order-to-cash cycles. These products enable access to liquidity by allowing suppliers to sell credit term invoices, unlocking working capital while mitigating risks and leveraging the lower cost of capital of a well-rated purchaser to reduce risk and costs throughout the supply chains. Asset-heavy companies may have to change their mindset to explore alternative forms of financing also to supplement their financial requirements to conclude the transactions efficiently. Those that fail to could be forced to sell assets or face a shut market in the long run (Narain, 2014). 


\section{AN ASSESSMENT OF TRADE FINANCE GAPS}

Trade finance gaps, particularly during and after the 2008-2009 global financial crisis, have become a persistent feature of the global trade regime. The Asia-Pacific region is also witnessing the same trend of a widening gap; "supply falling short of demand". Market gaps for trade finance in the Asia-Pacific region have persisted even as the global economy has recovered. Anti-money laundering regulations and companies lacking awareness of trade finance options were significant contributors to trade finance gaps, as observed by ADB (2014). However, measuring the trade finance gaps has proved to be a challenge.

The lack of comprehensive data on Asia-Pacific trade finance from a single source makes it difficult to realistically assess the demand-supply constraints and gaps. For the purpose of making an Asia-Pacific trade finance gap assessment, this paper, heavily relies on two important sources: (1) 2014 Rethinking Trade \& Finance (prepared by ICC and released in June 2014) and (2) ADB-Trade Finance Gap, Growth, and Jobs Survey 2013, released in December 2014 (the first series relates to the year 2012).

\section{ICC-Rethinking Trade \& Finance 2014}

The ICC-Rethinking Trade \& Finance 2014 report brought out three major findings from its survey participation of 298 banks in 127 countries:

(a) In comparison to the previous survey of 2012, there was a more positive global outlook regarding the availability of trade finance in 2013. However, 55 per cent of the surveyed banks believed that there was a shortfall of trade finance globally (ICC, 2014b, pp. 94-96).

(b) A gap between supply and demand persisted, even though more than 80 per cent of the respondents reported an increase in the number of credit lines offered in 2013. Trade finance constraints became more pronounced and concentrated in emerging markets for want of necessary skills to propose bankable propositions by entrepreneurs, which ultimately led to a high rate of rejections.

(c) Financial crimes triggering anti-money laundering/know your client (AML/KYC) requirements proved to be impediments to trade finance. Among firm types, SMEs were the most negatively affected.

The key findings of the ICC Global Trade \& Finance Survey 2014 are summarized below (box 3). 


\section{Box 3. Key findings of the ICC Global Trade \& Finance Survey 2014}

- While there are signs that trade finance is more available, the reported increase is marginal.

- The shortage of trade finance for international trade remains a major challenge for economic recovery and development.

- To finance exports and imports traders, SMEs in emerging markets, in particular, continue to rely on loans/overdrafts in local currency (rather than in foreign currency), restricting their ability to trade at optimum levels during challenging times caused by volatile exchange fluctuations.

- Encouragingly, 68 per cent of respondents reported that trade finance increased by value, but the rate was lower that for the previous year.

- The alarming rise in fees for trade risk after the 2009 trade collapse has abated.

- An enigma surfaced: a large gap remains in the market for trade finance and risk coverage even while 80 per cent reported trade finance pricing is lower or unchanged.

- A total of 69 per cent of the respondents noted a decline in reported court injunctions barring payment under trade finance instruments, indicating a return to normal trading conditions.

- Banks remain cautious in examining documents. Worryingly, only 7 per cent reported a decrease in spurious discrepancies when documents are presented under a letter of credit.

- Know your customer principles are seen as hampering the smooth flow of trade finance.

- Some 65 per cent said implementation of Basel III regulations is to some extent or a large extent affecting the cost of funds and liquidity for trade finance.

- Documented losses are low on trade finance products.

Source: $\quad$ ICC (2014b, p. 31). 
Results from the above surveys on trade finance gaps bring to focus a number of common factors responsible for narrowing the supply line across the board. SMEs, as a sector, were the worst hit subsegment of the Asia-Pacific economy. Despite the increase in bank credit (by volume), the overall trade finance gaps persisted.

\section{The Asian Development Bank - Trade Finance Gap, Growth, and Jobs Survey}

According to ADB, in 2013, the global trade finance gap was estimated at $\$ 1.9$ trillion. Of that amount, $\$ 1.1$ trillion was in developing Asia, and $\$ 699$ billion was attributed to India and China. Geographically, Asia recorded the highest share of proposed transactions at 57 per cent of the global trade and had the highest percentage (79 per cent) of global rejections, with India and China jointly recording 35 per cent of the rejected transactions (table 4).

Table 4. Distribution of proposed and rejected trade finance transactions in 2013 by region as percentage of global total

\begin{tabular}{lcc}
\hline Region & $\begin{array}{c}\text { Proposed transactions } \\
\text { (per cent) }\end{array}$ & $\begin{array}{c}\text { Rejected transactions } \\
\text { (per cent) }\end{array}$ \\
\hline Asia & 57 & 79 \\
Europe & 22 & 13 \\
Commonwealth of Independent States & 8 & 3 \\
Americas & 8 & 1 \\
Africa & 5 & 3 \\
\hline
\end{tabular}

Source: Compiled by the author using data from ADB Trade Finance Gaps 2013.

About 75 per cent of the banks reported that they had increased the level of credit lines in 2013 - firms and financial institutions reported a more positive situation about the availability of finance. As opposed to SMEs, large corporate companies tended to report sufficient availability of trade finance.

Some of the major findings of the ADB Survey are:

(a) Small and medium-sized enterprise constraints were more pronounced:

- The trade finance gaps affected SMEs more negatively than other company respondents.

- Rejection rates of trade finance applications were the highest for SMEs. 50 per cent of SME proposals were rejected in 2013 as compared to only 7 per cent for multinational corporations. 
- SMEs familiarity with various types of non-traditional methods to raise trade finance was limited.

(b) Commercial risk averse bank transactions had a negative impact:

- The risk factor in banking transactions acted as a systemic credit constraint.

- $\quad$ Sixty-one per cent of responding banks reported that AML/KYC due diligence requirements were significant impediments to the provision of credit.

\section{(c) Costs constrained access to finance:}

- $\quad$ More than 74 per cent of the respondent banks cited factors related to the price of trade finance as a key bottleneck to access.

- $\quad$ The high borrowing costs worked out mainly due to high interest rates/premiums, insufficient collaterals offered by SMEs and hence stringent credit terms imposed by financial institutions.

Impediments to the provision of trade finance identified by the ADB Survey are presented in table 5.

\section{Table 5. Impediments to the provision of trade finance}

\begin{tabular}{llcc}
\hline \multicolumn{1}{c}{ Impediments } & $\begin{array}{c}\text { Very significant } \\
\text { (per cent) }\end{array}$ & $\begin{array}{c}\text { Significant } \\
\text { (per cent) }\end{array}$ & $\begin{array}{c}\text { Total } \\
\text { (per cent) }\end{array}$ \\
\hline 1. Issuing bank's low credit ratings & 30 & 33 & 63 \\
2. Low country credit ratings & 33 & 29 & 62 \\
3. AML/KYC requirements & 43 & 18 & 61 \\
4. Low company/obligator credit ratings & 18 & 40 & 58 \\
5. Previous dispute or unsatisfactory & 31 & 21 & 52 \\
performance of issuing banks & & & \\
6. Insufficient collateral from company & 23 & 28 & 51 \\
7. Constraints on your bank's capital & 11 & 32 & 43 \\
8. Basel regulatory requirements & 17 & 24 & 41 \\
9. High transaction costs or low fee income & 18 & 21 & 39 \\
10. Lack of dollar liquidity & 7 & 28 & 35 \\
\hline
\end{tabular}

Source: Compiled by the author using data from ADB (2014, figure 3). 
According to the Survey, high interest rates/premiums followed by insufficient collateral or guarantee, were identified by the respondents as a very significant factor limiting companies' ability to obtain trade finance (table 6).

\section{Table 6. Factors limiting companies' ability to obtain trade finance}

\begin{tabular}{lccc}
\hline \multicolumn{1}{c}{ Impediments } & $\begin{array}{c}\text { Very significant } \\
\text { (per cent) }\end{array}$ & $\begin{array}{c}\text { Significant } \\
\text { (per cent) }\end{array}$ & $\begin{array}{c}\text { Total } \\
\text { (per cent) }\end{array}$ \\
\hline 1. Interest rates/premiums too high & 38 & 20 & 58 \\
2. Insufficient collateral or guarantee & 34 & 16 & 50 \\
3. Long processing time & 25 & 25 & 50 \\
4. Financial institution's requirements & 21 & 23 & 44 \\
$\quad$ unacceptable & 17 & 20 & 37 \\
5. Documentation requirements are too & 19 & 16 & 35 \\
burdensome & 19 & 13 & 32 \\
6. No previous transaction/lack of business & 18 & 10 & 28 \\
relationship & & & \\
8. My country has "high risk" ratings & 14 & 12 & 26 \\
9. Company records are incomplete/ & 14 & 10 & 24 \\
\hline unacceptable & 19 & & \\
\hline
\end{tabular}

Source: Compiled by the author using data from ADB (2014, figure 5).

(d) Non-traditional financial products were underutilized:

- Uptake of innovative products, such as supply chain finance, had been slow. One reason appeared to be information asymmetries.

- In the case of non-traditional products, such as factoring, forfaiting, bank payment obligation and supply chains finance, less than 40 per cent of companies reported familiarity with these instruments.

(e) Trade finance-contributor to production and employment growth:

- Responding firms indicated that additional trade finance would have a positive impact on production and employment levels. A 15-per cent increase in access to trade finance was estimated by them to increase production by 22 per cent. 
- $\quad$ Responses also suggest that greater access to trade finance would have a positive impact on employment levels. Respondents noted that a 15-per cent increase in trade finance may enable the firms to hire 17 per cent more staff.

The ADB Survey concluded by observing that significant trade finance gaps remained, and that SMEs continued to be credit constrained in every region. Narrowing of trade finance gaps would lead to more economic growth and job creation. Unintended consequences of (overlapping) regulatory requirements, particularly with respect to financial crimes compliance, were contributing to the gap. More outreach to companies about "non-traditional" forms of trade finance can contribute to closing trade finance gaps.

\section{EMERGING ISSUES AND CHALLENGES}

\section{Introduction}

While the surveys cited above clearly identify the short supply of finance as the most critical major factor causing trade finance gaps, a close look at the factors other than finance indicate that non-financial factors, such as high rate of credit rejections, high collateral/guarantee requirements, non-availability of timely credit, lack of adequate awareness about international trade and insufficient skills to make cross-border trade transactions and the risk-averse banking sector not willing to lend to SMEs, also indirectly affect the flow of trade finance and the efficacy of the institutional finance framework. This gives rise to a question as to whether the insufficient supply of institutional funds causing persistent gaps is the only major factor hindering trade development in the region. While on the one hand paucity of trade finance has been by far the largest complaint of the private sector, on the other hand, the Asia-Pacific region, despite the demand-supply gaps, has emerged as the largest user of trade finance in the global market. Europe, Latin America, Middle East, North America and Africa have followed the trail. This trend gives rise to certain policy implications and a clear signal to stakeholders to identify factors other than the paucity of bank-intermediated funds as barriers to growth. An attempt has been made in this section to identify the emerging issues and challenges that directly or indirectly affect credit flow, business growth and sustainability. Recently, many vexing issues have surfaced, giving rise to policy implications and posing systemic and operational challenges.

Concerns have also been voiced about the inadequate infrastructure of trade finance that would geographically cover and adequately service emerging markets in the region; an inadequate financial corpus, which leaves behind sizable gaps; a rigid 
banking system insensitive to the changing global market; unmet demands of information and communications technology-related transactions, such as e-marketing, and mobile banking, an absence of legal provisions and appeals in most of the Asia-Pacific countries and above all such electronic transactions not being recognized by the courts of law. The lack of innovative financial products and trade finance instruments is yet another area of major concern. ${ }^{2}$

The Asia-Pacific region is the largest user of bank-intermediated trade finance globally, yet it has lagged behind Europe in making effective use of inter-firm nonbanking trade transactions through supply chains, factoring, and forfaiting. These innovative non-banking channels offer scope to supplement the dwindling supply of trade credit available from the formal banking sector. Asia and Pacific economies, similar to many other economies in other parts of the world, are saddled with various operational issues and constraints within the region.

\section{Identifying the major factors and challenges}

Some of the major factors and challenges affecting credit flow and, more generally, the systemic and operational efficiency of the trade finance infrastructure in the Asia-Pacific region are discussed below:

(a) Trade finance demand and supply gaps persisted

A persistent trade finance gap has been the most critical constraint and an issue of growing policy concern in the Asia-Pacific region. This phenomenon, as noted earlier, has become a continuing feature of the Asia-Pacific financial sector.

(b) Small and medium-sized enterprises are the most credit constrained sector

Despite being the largest employer with a high potential of exports and a significant contributor to national economies, the SME sector is the most trade credit constrained segment of the Asia-Pacific economies. In addition, banks generally consider SMEs as highly vulnerable to market shocks and therefore are largely not viable customers for bank credit.

(c) Shortages of trade finance affect trade

Whether shortages of trade finance actually affect trade has been an issue of recent debates in academia, particularly after the global financial crisis of 2008-2009 (Chor and Manova, 2012; Berms, Johnson

2 See for example, International Trade Centre (2009, p. 36, box 3.4 "Pitfalls in trade transactions-a case study"). 
and Yi, 2010; Amiti and Weinstein, 2011; Bricongne and others, 2012; Auboin and Meier-Ewert, 2003; Aubion and Engemann, 2013). While most scholars agree that a fall in the demand for trade finance has been largely responsible for the slowdown and drop in trade flows, the debate has focused on the extent to which other potential culprits, such as trade restrictions, a lack of trade finance, vertical specialization, and the composition of trade, may have played a role. Market surveys conducted by ICC (2009), and IMF and BAFT-IFSA (2009) point to the sharp fall in trade finance during the financial crisis as the main reason for the drop in trade flows. Given the rapid decline in trade and emerging challenges, a number of protectionist trade policy measures were taken during 2008/09 by the policymakers and central banks around the world. The major policy responses can be viewed in CGFS (2014, box 3, p. 22). Although the exact amount of "missing" trade finance may remain unknown, the literature cited in this context has highlighted the wider link that exists between financial conditions, trade credit and trade (Auboin, 2015). Taken together, it transpires that credit shocks, including working capital and trade finance, possibly account for 15-20 per cent of the decline in trade during the crisis.

The recent financial crisis revealed that trade finance markets are vulnerable to abrupt dislocations (Auboin, 2015, para 2.2). The emerging markets and least developed countries are more prone to such shocks, making policy interventions and support essential to sustain the availability and flow of trade finance. Even with its large presence and pivotal role in making sizable contribution to Asia-Pacific economies, the SME sector remains highly vulnerable to market dislocations and exposed to volatility, especially in least developed countries.

(d) Inadequate trade finance infrastructure and network

The inadequate infrastructure and weak networks of financial institutions and poor geographical coverage of banking facilities in many parts of Asia and the Pacific inhibit the timely availability of trade finance to the private sector, including SMEs.

\section{(e) Absence of risk-mitigation mechanism}

Branch-line managers lend to SMEs only when such loans are backed by high collateral and third-party guarantees. The stipulation imposed by the banks asking for high collateral and third party guarantees has been a major barrier for companies in accessing trade finance. 


\section{Problems of least developed countries in accessing affordable trade finance}

Least developed countries, in particular, face the problem of accessing affordable trade finance. This has gradually resulted in a "trade finance divide" between the least developed countries and other developing economies of the Asia-Pacific region. The banking sector is generally wary of entertaining credit proposals in such countries; it tries to insulate itself against risks of loan defaults by charging higher interest rates backed by high collateral requirements and guarantee conditions.

\section{(g) De-risking bank transactions are a constraint}

De-risking requirements in bank transactions and interbank relationships have become a major systemic credit constraint. Regulatory requirements to mitigate the risk of financial crimes are compelling reasons for banks to sever bank-to-bank relationships, particularly in emerging markets. In particular, the AML/KYC due diligence requirements have become significant time-consuming impediments to effective trade finance access and have resulted in high compliance costs. These reporting requirements have led to a significant reduction in trade transactions in Asia and the Pacific.

(h) Advantages of low-risk letters of credits have yet to make inroads in emerging markets

Given the fact that L/Cs are a low-risk, safe and a more reliable mode of trade finance transactions, many least developed countries, especially those in the Pacific subregion, have yet to become fully aware of the potential and advantages of L/Cs. Unfamiliarity with this instrument and high transactional costs are perceived as the main obstacles.

(i) Awareness and uptake of both existing and new financing structures and products has been limited

Global banks view supply chain finance as an important new area of activity, and a focal point of current competition. Citing new regulatory demands and high marginal costs of equity capital, the trade finance industry is experimenting with new structures and products to distribute the exposure of trade finance to non-bank investors. To date, the scale of this activity has been limited and is not likely to pick up considerably in the near future (CGFS, 2014).

The reach and uptake of non-financial products, such as supply chain related finance and factoring, has been slow. Information asymmetries appear as a main reason, as less than 40 per cent of responding 
companies reported familiarity with these non-traditional products in an earlier cited ADB survey. Even familiarity with established products, such as credit insurance was limited (ADB, 2014).

\section{(j) Banking sector does not catch early warning signals}

The global financial crisis of 2008-2009 and consequent strains in 2011-2012 adversely affected the trade finance sector. Bank finance exposure in almost all countries fell sharply soon after U.S. investment bank Lehman Brothers filed bankruptcy. The banking sector failed to effectively catch early warning signals. Trade finance disruptions had a secondary but economically significant role in the sharp reduction in global trade volumes. Given their short-term nature, banks have been able to quickly reduce their exposure in times of stress. However, because of this latter feature, trade finance has acted as a conduit of stress from the financial system to the real economy (CGFS, 2014).

(k) Emerging markets in the Asia-Pacific region tend to be less globally integrated

Asia-Pacific countries are very well integrated into the global trading system, but they are lagging in terms of financial integration. Emerging markets in Asia and the Pacific tend to be less globally integrated than the markets of other countries. As always, there are exceptions. Malaysia, with a large and active institutional investor base, is as globally integrated as any emerging market. In contrast, India and Indonesia are at the other extreme and have smaller international investment positions than emerging markets in other regions (Walsh, 2014).

\section{POLICY IMPLICATIONS AND RECOMMENDATIONS}

\section{Implications}

The issues and challenges identified above give rise to various policy implications. The matrix below presents an overview of these implications in a tabular form (table 7). In this context, it is desirable that the policies are periodically reviewed and securely aligned with expanding demand for trade finance. They should be market-oriented and designed to adapt to future change. In particular, they should aim at (a) strengthening inbuilt stability of the trade finance sector, (b) increasing competitive resilience, (c) adequately insulating the sector from possible market shocks, (d) limiting the negative spillover effects likely to affect the national economy, and in particular, (e) addressing the following issues: 
(i) How to make trade finance innovative, resilient, stable and relevant to changes occurring in the trading environment;

(ii) How to insulate trade finance, such as pre-shipment and post-shipment, from market shocks and related credit risks;

(iii) How to structure central banking credit policies to ensure adequate resource support to the banking sector and set up risk mitigation mechanisms, which would encourage banks to lend without inhibition;

(iv) How to effectively monitor market developments and disseminate market intelligence to policymakers to help them make informed policy decisions;

(v) How to design and set up an effective mechanism to catch early warning signals to alert the financial sector of risks and shocks well on time.

Table 7. Matrix of trade finance conceptual, systemic and structural issues and policy implications

\begin{tabular}{l|l}
\hline Conceptual, systemic and structural issues & \multicolumn{1}{c}{ Policy implications } \\
\hline $\begin{array}{l}\text { Conceptual changes needed to address } \\
\text { the supply side: Some of the traditional trade }\end{array}$ & $\begin{array}{l}\text { New concepts and instruments, such as } \\
\text { innovative non-finance and non-bank } \\
\text { intermediated instruments (often supply chains }\end{array}$ \\
$\begin{array}{l}\text { are no longer relevant to the changed context } \\
\text { of global trade transactions. As a result, the } \\
\text { supply side of trade finance falls short of } \\
\text { remand and trade finance gaps are increasing. } \\
\text { satisfy unmet demand for trade finance and } \\
\text { close the trade finance gap. }\end{array}$ \\
$\begin{array}{l}\text { SME demand side of trade finance is } \\
\text { not well served }\end{array}$ & $\begin{array}{l}\text { In particular, additional attention should be } \\
\text { given to the trade financing needs of } \\
\text { SMEs through the implementation of viable } \\
\text { government-sponsored financing and credit } \\
\text { guarantee programmes aimed at risk mitigation } \\
\text { and cost reduction of credit. }\end{array}$ \\
\hline $\begin{array}{l}\text { Systemic and structural changes are } \\
\text { highly required }\end{array}$ & $\begin{array}{l}\text { The administrative, legal and banking systems } \\
\text { need to be given a holistic reassessment, which } \\
\text { leads to an identification of structural factors } \\
\text { and constraints that need to be addressed to } \\
\text { allow steady credit availability. }\end{array}$ \\
\hline $\begin{array}{l}\text { Lack of skills and capacity: SME borrowers } \\
\text { of trade finance are generally not aware of the } \\
\text { products available; they lack skills and access }\end{array}$ & $\begin{array}{l}\text { Suitable measures need to be adopted to } \\
\text { sensitize and improve the low credit rating of } \\
\text { banks. Develop capacity-building programmes } \\
\text { for training SME clients. }\end{array}$ \\
\hline
\end{tabular}




\section{The need for change of future trade finance}

From the previous sections, an important conclusion emerges: for trade finance systems in the Asia-Pacific region to be relevant in the future, they need to be globally competitive, innovative, cost-effective and sustainable to effectively address needs-based "changes". The banking system should work with non-banking channels to supplement the supply side of trade finance. This may partially reduce the pressure on banks. The systemic and operational changes need to be made on an ongoing basis, adopting a holistic approach to both financial and non-financial factors of change.

The Society for World Interbank Fund Transfer (SWIFT) and the Fung Global Institute have jointly reviewed trade flows in Asia and observed the following: "By 2020, the Asian region is expected to account for almost 35 per cent of world GDP, compared to 27 per cent today. Finance is still stuck in the letters of credit and multilateral support world, but [...] times will change quite rapidly." This raises a very basic question: whether trade finance and trade finance products in their present form will be able to keep pace with the expanding demand and changes in the future? The Asia-Pacific trade finance sector is large, diverse and differs in many ways from similar sectors in other parts of the world, especially in least developed countries, but is not yet as sophisticated as those in Europe or America. Most Asia-Pacific banks also tend to be more focused on providing traditional bank-intermediated trade finance and are averse to taking commercial risks.

"As Asia leads the world in growth, will its financial systems lead too", observed James P. Walsh, Deputy Division Chief of the Monetary and Capital Markets Department of IMF. He further stated: "Across Asia, the rapid growth of financial sectors is an important part of the growth miracle that has made Asia the world's most dynamic region. Analysts look closely at the financial risks that Asia faces today, but sometimes it's interesting to look farther forward. So with this dynamism expected to continue, what will Asian financial sectors look like in the future?" (Walsh, 2014)

The role of international institutions is important to make trade finance responsive to change and resilient. ADB, ESCAP and the World Trade Organization (WTO) could coordinate efforts for this purpose by forming a joint group, which would initially concentrate on the following:

(a) Play a diagnostic and advisory role to alert, aid and advise the AsiaPacific public and private sector trade finance community on trends, development, pending changes and shocks;

(b) Provide international support to Asia-Pacific economies to help them augment trade finance resources; 
(c) Strengthen the capacity of both banking and non-banking actors to provide trade finance by improving their stress management capacity, resilience, openness and adaptability to change;

(d) Work out synergies for providing technical assistance to developing countries in this area;

(e) Monitor trade finance markets to disseminate timely market intelligence and early warning signals.

\section{Policy recommendations}

A review of trade finance policies and programmes to identify conflicting issues, emerging challenges and resultant policy implications is essential. For that purpose, this paper presents a set of policy recommendations, adopting a holistic approach. The challenges confronting trade finance have been addressed from the lenders' and borrowers' angle, and after taking due cognizance of the realities on the ground. The matrix of suggested policy recommendations is presented in table 8 .

\section{Table 8. Suggested policy recommendations}

Conceptual
- Redefine the traditional concept of working capital by splitting it into two: (a) conventional working capital (for day-to-day operations up to the pre-shipment stage); and (b) trade finance and market development working capital, such as short-term credit, export credit, insurance, risk mitigation charges and, exchange fluctuations, and all post-shipment trade related transactions.

For the latter, trade-related market development services need to be developed, such as trade fairs, fashion shows, market forecasts, product and design development, capacity-building for development of viable and bankable business plans, which will ultimately reduce the rates of rejections increase the supply of bank intermediated funds; product development in the global market and identification of potential markets to attract potential business.

- Set up and enlarge the scope and coverage of a national exchange fluctuation fund to cover all export-import transactions. This may be set up as a national fund to cover the negative impact of exchange fluctuations. ADB could link up with central banks to design and operate the fund. Risk coverage should be available for up to 100 per cent for SMEs and 90 per cent for other companies. SMEs would pay premiums at subsidized rates. This would halt the default rate. Modalities can be worked out once this is accepted as a concept.

- Supply chains and factoring transactions of the private sector should be defined as negotiable financial instruments. This would promote 


\begin{tabular}{|c|c|}
\hline & $\begin{array}{l}\text { markets for securitization of such instruments and augment supply of } \\
\text { the trade finance. }\end{array}$ \\
\hline $\begin{array}{l}\text { Government \& } \\
\text { sector public }\end{array}$ & $\begin{array}{l}\text { - Design trade-friendly export-import policies aimed at the } \\
\text { development of both domestic value-added trade activities and } \\
\text { exports/imports. } \\
\text { - National governments and central banks should promote effective } \\
\text { policies to make the trade finance sector stable, forward looking and } \\
\text { vibrant and to cushion the after-effects of any financial crisis. } \\
\text { Develop a suitable legal frameworks and appeal system for redressing } \\
\text { grievances arising out of international transactions. } \\
\text { - Strengthen collaboration with international agencies, such as the } \\
\text { Centre for the Promotion of Imports - the Netherlands and IFC for } \\
\text { ongoing market tie ups, generating market intelligence and technical } \\
\text { assistance. } \\
\text { Implement sufficient trade facilitation measures to contain trade } \\
\text { transaction and transportation costs. } \\
\text { Strengthen trade facilitation and trade finance mechanisms in } \\
\text { multilateral, regional and bilateral trade agreements. } \\
\text { Trade missions attached to the embassies should support the private } \\
\text { sector as central points for trade related matters, such as help in } \\
\text { establishing supply chains contacts, making forecasts. } \\
\text { Introduce risk-free e-marketing and online procurement mechanisms } \\
\text { backed by suitable legal and regulatory frameworks. }\end{array}$ \\
\hline $\begin{array}{l}\text { Central banks } \\
\text { and the financial } \\
\text { sector }\end{array}$ & $\begin{array}{l}\text { While most of the Asia-Pacific central banks have been proactive and quite } \\
\text { vigilant in making need-based changes in trade finance policies governing } \\
\text { banks, some of them have to enhance the stability and resilience of their } \\
\text { banking sector. } \\
\text { - In view of the persisting trade finance gaps, in addition to releasing } \\
\text { liquidity supply to the banks, trade finance supply through non- } \\
\text { traditional/non-financial channels with adequate safety net and risk } \\
\text { minimization mechanisms needs to be expanded. } \\
\text { - Encourage companies to enter open market borrowings. The SME } \\
\text { sector will need special dispensation to do this. } \\
\text { Encourage and institutionalize inter-firm credit systems, mains- } \\
\text { treaming them in cooperation with banks and with adequate risk } \\
\text { mitigation support. } \\
\text { Instil confidence and encourage banks to lend without any inhibition, } \\
\text { introduce suitable risk mitigation, export credit insurance and } \\
\text { workable guarantee mechanisms. Set up a guarantee fund to extend } \\
\text { guarantee cover to collateral-free cum third party guarantee-free bank } \\
\text { loans to SMEs. }\end{array}$ \\
\hline
\end{tabular}




\begin{tabular}{|c|c|}
\hline & $\begin{array}{l}\text { - Central banks should simplify the de-risking element in bank } \\
\text { transactions and AML/KYC due diligence requirements as these } \\
\text { requirements have been identified as a major source of systemic } \\
\text { credit constraint. }\end{array}$ \\
\hline $\begin{array}{l}\text { International and } \\
\text { multilateral } \\
\text { Institutions }\end{array}$ & $\begin{array}{l}\text { - Asia-Pacific countries are very well integrated into the global trading } \\
\text { system, but financial integration has lagged. Emerging markets in Asia } \\
\text { and the Pacific tend to be less globally integrated. ADB and the Worlo } \\
\text { Bank should lend support to national governments and central banks } \\
\text { to accelerate the financial integration of emerging economies. } \\
\text { - ADB should take the lead in collaborating with other international } \\
\text { institutions, such as IFC, to set up an Asia-Pacific trade development } \\
\text { fund for funding innovative and non-financial products, inter-firm trade } \\
\text { credits and trade development services that have not been funded by } \\
\text { the banking sector. Assistance can be given to companies through } \\
\text { their local banks backed by a suitable collateral-free guarantee } \\
\text { mechanism. The participating banks/companies need to participate in } \\
\text { the share capital to become members eligible to get a suitable line of } \\
\text { credit from the fund. Detailed operational modalities can be } \\
\text { developed at a later stage. } \\
\text { A joint group comprised of ADB, ESCAP and WTO may be set up to } \\
\text { monitor trade and trade finance trends and developments, and alert, } \\
\text { aid and advise Asia-Pacific trading communities and governments to } \\
\text { enhance the resilience of the banking and financial sector in the } \\
\text { region. }\end{array}$ \\
\hline Private sector & $\begin{array}{l}\text { - ICC should be made the central agency for compiling global } \\
\text { and regional trade finance data/information for use by various } \\
\text { stakeholders. This will enhance the capacity of ICC to add value to its } \\
\text { leading publication, the ICC Trade Register. To enlarge the reach and } \\
\text { supplement the coverage of its ongoing annual series of surveys and } \\
\text { publications of the Trade Register, all concerned should agree to } \\
\text { supply relevant information to ICC for this purpose. } \\
\text { ICC, in collaboration with ESCAP, ITC and national chapters/apex } \\
\text { chambers and export agencies could organize capacity-building } \\
\text { programmes on, for example, international trade, exports, trade } \\
\text { facilitation and the WTO regime. }\end{array}$ \\
\hline
\end{tabular}

Note: a The Committee on the Global Financial System in its report on trade finance development and issues 2014 , has cited the findings of various surveys conducted by the World Bank and others, "firms that were more reliant on trade credit to fund their own operations (and hence less reliant on bank funding for working capital) were less affected" during the financial crisis. Fourteen developing countries show that trade credit was relatively more resilient than bank credit during the 2008-2009 global financial crisis (CGFS, 2014, p. 55). 


\section{REFERENCES}

Abe, Masato, and others (2012). Policy Guidebook for SME Development in Asia and the Pacific. United Nations publication, Sales No. E.12.II.F.2.

Amiti, Mary, and David Weinstein (2011). Exports and financial shocks. Quarterly Journal of Economics, vol. 126, No. 4, pp. 1841-1877.

Asian Development Bank (ADB) (2014). ADB trade finance gap, growth, and jobs survey. Briefs, No. 25 (December). Manila.

Auboin, M., and M. Engemann (2013). Trade finance in periods of crisis: what have we learnt in recent years? Staff Working Paper, ERSD-2013-01. Geneva: World Trade Organization.

Auboin, M., and M. Meier-Ewert (2003). Improving the availability of trade finance during financial crises. Discussion Paper, 2. Geneva: World Trade Organization.

Auboin, M.G. (2015). Improving the availability of trade finance in developing countries: an assessment of remaining gaps. Staff Working Paper, No. ERSD-2015-06. Geneva: World Trade Organization.

Bems, R., R.C. Johnson, and K.-M. Yi (2010). Demand spillovers and the collapse of trade in the global recession. IMF Economic Review, vol. 58, No. 2, pp. 295-326.

Bricongne, J.-C., and others (2012). Firms and the global crisis: French exports in the turmoil. Journal of International Economics, vol. 87, No. 1, pp. 134-146.

Chor, D., and K. Manova (2012). Off the cliff and back? Credit conditions and international trade during the global financial crisis. Journal of International Economics, vol. 87, No. 1, pp. 117-113.

Committee on the Global Financial System (CGFS) (2014). Trade finance: developments and issues. CFFS Papers, No. 50. Basel, Switzerland: Bank for International Settlements.

Duval, Yann, and Chorthip Utoktham (2014). Enabling participation of SMEs in international trade and production networks: trade facilitation, trade finance and communication technology. Trade and Investment Division Working Paper, No. 03/14 (June). Bangkok: ESCAP.

Factors Chain International (2014). Annual Review 2014. Amsterdam, the Netherlands. Available from www.fci.nl.

International Chamber of Commerce (ICC) (2009-2013). Rethinking Trade \& Finance - ICC Global Survey on Trade Finance. Paris.

(2014a). 2014 ICC Trade Register Report. Paris.

(2014b). 2014 Rethinking Trade \& Finance - ICC Global Survey on Trade Finance. Paris.

International Finance Corporation (IFC) (2012). Guide to products: global trade \& supply chain solution, April. Available from www.ifc.org/wps/wcm/connect/2280e4804adf1618d 30ff888d4159f8/GFM-TSC8-IFC-GuideToProducts.pdf?MOD=AJPERES.

International Monetary Fund (IMF), and Bankers' Association for Finance and Trade and International Financial Services Association (BAFT-IFSA) (2009). IMF-BAFT trade finance survey: a survey among banks assessing the current trade finance environment.

(2010). Trade finance services: current environment and recommendations: wave 3. 
(2011). Trade finance monitor: 6th annual trade finance survey . Available from http:// baft.org/docs/news-archive-2012/imf_survey_results_aug_2011.pdf?sfvrsn=0.

International Trade Centre (ITC) (2009). How to Access Trade Finance: A Guide for Exporting SMEs. Geneva.

MacMillan, Johan, and Christopher Woodruff (1999). Interfirm relationships and informal credit in Vietnam. The Quarterly Journal of Economics, vol. 114, No. 4, pp. 1285-1320.

Narain, Raghu (2014). Asset-heavy firms should explore different forms of financing. Insight, July. Edinburgh, United Kingdom: Royal Bank of Scotland. Available from www.rbs.com/insight.

United Nations, Economic and Social Commission for Asia and the Pacific (ESCAP) (2007). Linking Greater Mekong Sub-region Enterprises to International Markets: The Role of Global Value Chains, International Production Networks and Enterprise Clusters. Studies in Trade and Development, No. 59. Bangkok.

(2009a). Asia-Pacific Trade and Investment Report 2009: Trade-led Recovery and Beyond. Sales No. E.09.II.F.19.

(2009b). Globalization of Production and the Competitiveness of SMEs in Asia and the Pacific: Trends and Prospects. Studies in Trade and Investment, No. 65. Bangkok.

(2014). Statistical Yearbook for Asia and the Pacific 2014. ST/ESCAP/2704. Bangkok.

Walsh, J. (2014). The future of Asia's finance. Finance \& Development, vol. 51, No. 2 (June). Available from www.imf.org/external/pubs/ft/fandd/2014/06/walsh.htm.

Zhang, Yuhua (2014). Integrating SMEs into global value chains: policy principles and best practices. IssuesPaper, No. 6. Singapore: Asia-Pacific Economic Cooperation. Available from www.insme.org/insme-newsletter/2014/file-e-allegati/newsletter_documents/Integrating SMEs.pdf. 
